\title{
The Society of Individuals: How to Solve the Dilemma of Individualism and Holism in Historical Sociology
}

\author{
JIĽ́ Ś UBRT**
}

Společnost individuí: Jak vyřrešit dilema individualismu a holismu v historické sociologii

\begin{abstract}
One of the questions that Norbert Elias tries to resolve in his work - either explicitly or implicitly - is the issue of the relationship between the individual and society. Elias critically assesses two approaches to this issue that sociology offered in his time, namely the Weberian conception of individualism that postulates the human individual as the starting point of sociological thought, and the Durkheimian conception of holism, which considered society as a whole as the starting point, giving regard to holistic, supra-individual social facts. Elias considers both of these solutions one-sided and unsatisfactory, and in his conception tries to supercede them. His strategy is close to that of Georg Simmel before him. It consists in highlighting the "third" that lies between the individual and society, which connects them. Simmel calls this "third" "Wechselwirkung". Elias speaks about "figuration". In this article, we consider how successful Elias' strategy is, its merits and its shortcomings. At the end of the text, the author attempts to formulate his own solution of the discussed problem, which is different from Elias's approach and based on the concept of "homo duplex".
\end{abstract}

Keywords: individualism; holism; human individual; action; structure; figuration; homo duplex

DOI: $10.14712 / 23363525.2015 .2$

Norbert Elias's book, The Society of Individuals, constantly comes back to the problem that the author characterizes as a gap in Western thinking which has opened up between the individual and society and is not easy to bridge [Elias 2006: 25]. There are two opposing parties of opinion: the proponents of one view claim that "Everything depends on the individual," while others believe that "Everything depends on society". The former argue that there are always particular individuals who decide what will and will not be done. The latter argue that what individuals do is always socially conditioned [ibid.: 68].

All our thinking is thus affected by antinomies. We have an idea of what we are as human individuals and also some idea of what society is, but these two images are not a very good fit. Nevertheless there is no doubt that individuals make up society and every society is a society of individuals [ibid.: 15]. Although we suppose that the "gap" between the individual and society does not really exist, our way of thinking is influenced by this polarity, which constantly fissures it. One of the issues that Elias focused on in his sociology is how to overcome this polarity of thought and bridge the long-standing metaphorical gap.

The antinomies which Elias referred to are associated with various terminological references in current theoretical literature. Jeffrey C. Alexander [1987] distinguishes between

* This study was written within the framework of the project "Homo Sociologicus Revisited" (No. 15-14478S) supported by the Czech science foundation GAČR.

** Doc. PhDr. Jiří Šubrt, CSc., Charles University in Prague, Faculty of Humanities, Department of Historical Sociology, U Krríže 8, 15800 Prague 5 - Jinonice. E-mail: jiri.subrt@fhs.cuni.cz. 
individualistic and collectivist theories. In the book, Contemporary Philosophy of Social Sciences, Brian Fay employs the mutual counter-position conceptual pair - atomism and holism. According to atomism, each individual represents a distinct unit of social life endowed with the ability to "control their own action on the basis of their beliefs and desires" [Fay 2002: 45]. Atomists understand society as a collection of individuals and at the same time consider social units to be transferable to the activities of the individuals who create them. Fay connects atomism with the strong belief in the "fundamental singularity of individuals", who are considered "as if what they are, were independent of their relations to other people" [ibid.: 46]. He considers Thomas Hobbes to be the philosophical founder of atomism, while in the social sciences of the 20th century this position is strongly represented by Friedrich von Hayek, who argues that social phenomena cannot be understood other than through understanding the individual acts of individuals. In sociology the origins of such methodological individualism are associated with Max Weber.

The opposite of atomism is holism, which Fay describes as the doctrine, "according to which the properties of individuals are solely a function of their place in society or some broad system of meanings" [ibid.: 67]. According to holism it is always necessary to take social units as the basis of social theory, not their individual members. Holism does not allow for theories of social units to be reduced or transfered to theories of individuals. For the social sciences a key personality of holism is Émile Durkheim; Fay considers the modern version of holism to include structuralism in particular (Lévi-Strauss, Foucault and others).

The opposition that Fay describes has a number of aspects that can be expressed in the form of related dualisms. Derek Layder mentions three of them in his book Understanding Social Theory [1994: 3]. There are the dualisms: individual - social, micro - macro and action - structure. The distinction individual - social, which the author considers to be the oldest and also the most persistent dilemma of sociological thought, corresponds in principle with the opposition atomism - holism, addressed by Fay. Layder points out that the problem of this dualism lies in the fact that individuals cannot be placed in sharp opposition to society simply because many of the needs and motivations that influence human individuals are produced by the social environment of the society in which they live. Put simply, there is no society without the individuals who define it, and the same time there are no individuals beyond the influence of society [ibid. 1994: 3].

\section{Individualism versus holism}

The individualistic (atomistic) interpretation presumes that in all social action the individual is the starting point, often referred to as the (individual) actor and his action, which carries a certain sense of meaning. Individualistic opinion assumes that all social phenomena consist of the many different, interrelated and interconnected actions of individuals, and moreover that these - often complex - phenomena can be retrospectively attributed to the actions of individual actors. The principles of individualistic sociology were formulated by Max Weber.

For Weber, Sociology is the science of social action. In his 1913 essay Über einige Kategorien der verstehenden Soziologie he notes that the subject of sociology is the social action of individuals and its aim is to understand and explain the course of this action through the meaning that the acting individuals themselves attributed to it [Weber 1988: 432-438]. 
In his later work Basic Sociological Terms, Weber characterizes sociology as a science to understand social action and thereby causally explain its course and its effects [Weber 1998: 136]. A key element in this concept is the German term Verstehen - understanding, from which is derived the designation of Weber's sociology as die verstehende Soziologie understanding sociology.

In terms of Weber's sociology all social phenomena, formations, and the entire social order, are human creations which consist of social relationships between acting individuals that pursue their own goals and value orientations; they are series, or complexes, of the interconnected actions of human individuals.

Generally speaking, individualistic opinion attributes primacy to the subjective, sovereign, individual free will, applied in the actions of human individuals. The individualistic perspective brings a "view from below" that sees the individual as an actor who creates social reality with his activities on the basis of how he understands the world affairs around him, how he interprets them and what meaning or significance he attributes to his actions. Society, social institutions, structures and systems, are something built (if need be constructed) from below, as a result of the interconnected actions of individuals, and thus the result of interpersonal interactions.

Holism, on the other hand, is based on the philosophical assumption that the whole is more than the collection of its component parts. Therefore social reality cannot be explained by reference to individuals and their individual actions, but must be explained on the basis of its own principles. Émile Durkheim claims that the subjects of sociology are so-called social facts, whose primary feature is that they are supra-individual, external to the individual, and entering consciousness as something external, independent of the will. The second essential characteristic is that they are endowed with coercive power and are able to exercise social pressure for the individual to conform to [Durkheim 1926: 36-37, 46].

Examples of social facts for Durkheim are such phenomena as religion, language, law or morality. In the book The Elementary Forms of Religious Life, he says: we speak a language which we have not ourselves created, we use tools which we have not ourselves invented, and we claim rights which we have not ourselves established. Each successive generation inherits a sum of knowledge which it did not collect itself and which it owes to society. The environment in which we live seems to us to be populated by forces that control us, but are also helpful to us. And these forces influence us by pressure which we conform to [Durkheim 2002: 235].

Durkheim sees society as a reality of a special kind which cannot simply be identified with the sum of its individual parts, because it has its own specific qualities that cannot be transferred to individuals. In relation to the individual it is the social or collective that is determining and that the individual submits to. Society has primacy over the individual in that it existed long before the individual and will be there long afterwards. It is the whole that has the ability to force individuals to live and act in a certain way. In the holistic perspective, individual actions are seen not as a result of the sovereign decision of the individual, but as a consequence of social (functional) pressures that society imposes on human individuals, which they obey.

The history of the sociology of the 20th century shows that both lines of interpretation - individualistic and holistic - presented viable exploratory strategies that transformed 
themselves into many specific forms, into a series of sociological schools and specializations. Through the individualistic approach we can encounter utilitarian theories, based on the concept of homo oeconomicus (exchange theory, rational choice theory), but also interpretive sociology (in particular, phenomenological sociology). From holism on the other hand arise first and foremost structuralism, then functionalism and systems theory. However, alongside this, several exploratory approaches emerged in the 20th century which viewed both these tendencies as one-sided and limited, and attempted to overcome them by bridging or linking them. In the framework of this movement we can include the contribution to sociological theory of Norbert Elias.

Elias in his sociology seeks quite systematically to overcome the contradiction between Weberian and Durkheimian sociology. Both approaches, according to Elias, commit the same mistake - an artificial, analytical separation of the individual and society which they use to emphasize divergent perspectives. Our thinking moves between the two extremes which permeate sociological theory; the first understands the individual as being outside society, and the second society as in opposition to the individual. The problem of the relationship between the individual and society is, according to Elias, unresolved in sociology.

Both individualism and holism tend to take their starting points (in one case the personality of the individual, in the other, the objectivity of supra-individual social reality) as something distinctive which has a privileged position, both in the ontological and epistemological senses. Both interpretative lines at the same time face certain problems, limits and restrictions; in both cases there is a danger of reductionism and simplification. Individualism is strong in the interpretation of phenomena taking place at the micro social level, but usually it has trouble capturing what goes beyond the level of individuals and their interpersonal relationships. It lacks the theoretical tools for the explanation of such macro-social phenomena as culture, civilization, modernization, industrialism, globalization or the social functioning of societal subsystems. In other words, individualistic thinking has a problem with grasping what goes beyond the level of interaction. Representatives of individualism are not commonly willing to admit that some processes are systemic in nature, i.e. their driving force is the system itself and its structures, and that some processes launch a systemic logic independent of the will of individuals.

Even when they emphasize individualism - in terms of the individual's voluntarism and free will - holistic approaches tend to credit all the supra-individual influences, pressures and systemic processes that are independent of the will of individuals. Behind everything, holism sees specific manifestations of supra-individual entities or the functioning of the social structures, systems or subsystems which individuals must go through. The exclusion of individuals from the perspective of theoretical thinking leads holism to attribute vital functions to social wholes - which means systems. Supporters of holism tend to consider the macro level of social reality; as for individuals, they ignore their subjectivity and individual initiative, and on the contrary emphasize conformity and subordination. Elias subjected both tendencies to criticism. He believed that neither leads to an adequate understanding of society. One recognizes it only as an aggregate of individuals, the other as something that exists outside individuals and independently of them [Elias 2006b: 7].

Supporters of individualism, according to Elias, tend to base themselves on the "atoms", the "smallest particles" of society. Individuals represent the firm "posts" between which 
stretch the temporary "strings" of interpersonal relationships [ibid.: 28]. For those who are used to thinking in an individualistic way, it is difficult to understand that social relationships may have their own structure and natural development [ibid.: 26]. On the contrary Elias emphasizes that each individual human being lives nestled into a network ("entanglement") of interpersonal relations, in which a number of features are dependent on others, and others are dependent on them. These relationships are at least partially reflected in personal character. The structure of these relationships is different in different types of societies, and no individual, whatever their personal qualities and dispositions, can break out of period-given facts and social frameworks, and nor meanwhile can they transform them [ibid.: 23, 63]. Moreover, each society has its own history and is able to change in a way that none of the individuals who jointly formed it anticipated or intended. Therefore, according to Elias, we must wonder how it happens that the coexistence and interaction of many human individuals leads to the creation of something new, which no one ever strived for and which nobody planned.

As for holism, the supporters of this school, according to Elias, usually proceed from a model of thought based on the biological way of thinking. They imagine society only as something supra-individual, as a supra-individual organic substance that exists beyond individuals. As a holder of social principles, it is labelled the "collective spirit", the "collective organism", or - in analogy with the forces of nature - supra-individual spiritual or material "forces" [ibid.: 26-27]. In this way of thinking there is no place for individuals.

According to Elias, neither of the two described tendencies adequately grasps what is going on in social reality, and consequently there opens an unbridgeable gap between social and individual phenomena. If we want to understand them correctly, we need to change our way of thinking, to abandon thinking focused on separate substances and move on to thinking focused on relationships and functions [ibid.: 28]. The structures of the human psyche, the structures of human society, and the structure of human history, do not exist as separately as it appears they do in today's research. On the contrary, they are inseparable, complementary phenomena that can be explored only in their mutual relations [ibid.: 49].

During the 20th century there were other theorists who attempted to overcome the antinomy of individualism and holism. First of all there was Talcott Parsons, who, in his work The Structure of Social Action, tried to interconnect the ideas of Weber and Durkheim [Parsons 1966]. Later, there was Peter L. Berger and Thomas Luckmann [1999], Jürgen Habermas [1981], Pierre Bourdieu [1998], Anthony Giddens [1984], Roy Bhaskar [1978], Margaret Archer [1995], Bruno Latour [2005], Luc Boltanski and Laurent Thevenot [2007], and many others. In principle it is possible to distinguish in this effort two basic strategies. The first is based on postulating some "third" that is placed as a bolt between the individual and society to connect both poles. The second is led by the effort to bring together both poles - individual and collective - and put them into a single explanatory framework, so that in the explanation of social events these perspectives are alternated.

The origins of the first strategy can be traced back to Georg Simmel, whose conception of sociology can be interpreted as a response to the dispute between sociological nominalism and realism [Keller 2004: 357]. Extreme nominalism is the claim that only human individuals really exist, not society. Realism - on the contrary - not only ascribes objective existence to society and other social wholes, but in addition has a tendency to put society 
above the individual. Simmel's definition of sociology tries to take a specific position that avoids the extremes. Simmel stands apart from nominalism, emphasizing the primacy of sociability over individuality, and moreover admits that interactions between individuals result in specific social qualities that are not original to the acting persons. However, at the same time he distances himself from realism, from the substantialist concept of social reality, and emphasizes its processual character. Society, according to Simmel, does not exist as a substance, but always as interaction between individuals [Simmel 1970: 27]. Simmel believes that society exists only because it is moment by moment re-created by the interaction of people, in which various forms of interpersonal association are lastingly formed, reproduced, but also abolished. Simmel highlights this as the third and the most important social phenomenon and refers to it as Wechselwirkung.

A typical example of the second approach is Anthony Giddens and his theory of structuration, in which the individual pole is represented by the term action, and the social pole by the name structure [Giddens 1984]. Giddens's theory is based on a duality theorem of action and structure, which states that structures are the product of human action, but, once formed, they represent a tool for other human action; a tool which on the one hand allows such action, but on the other, directs and limits it. Giddens - simply put - shifts his standpoint throughout his theoretical interpretation to explain observed issues by alternating individualistic and holistic positions. Essentially, he says: the first step is to adopt an individualistic position because it is individuals whose actions create structures; however, the second step is to adopt a holistic perspective, as these already-formed structures affect subsequent individual actions. The third step is to return to the individualistic point of view as individuals by their actions enable the existing structures not only to reproduce but to modify and transform.

These outlined strategies are not too different from each other; on the contrary they are complementary and have various points of contact. Regarding Elias, his solution to the question of relations between individual and society is the closest to Simmel's, which he freely develops and deepens, and whose concept Wechselwirkung he replaces by the expression "meshing" (Verflechtung) of relations and then particularly by the concept of figuration. But Elias's effort is at the same time associated with the effort to bring the two poles of the relationship - individual and society - together as closely as possible and to look alternatingly from both perspectives at ongoing social processes.

\section{Elias's concept of figuration}

Elias tried to overcome the extremes of individualism and holism - the two poles of social science - and to unify them, particularly by working out the concept of figuration, on which he focused especially in the book What is Sociology? [Elias 1970], but also in his other works (for example The Court Society [Elias 1983], The Established and the Outsiders [Elias - Scotson 1990]). The introduction of the concept of figuration is among his theoretical innovations. Through this concept he tries to overcome the traditional ideological polarization which pits subject against object, the individual against his surroundings (represented by various social groups), people as individuals against people as society. Figuration is, for instance, family, school class, rural community or state. At first glance, it might seem that this term is close to what is commonly referred to in sociology as a social group, 
but it is not like that. The concept of figuration draws attention to the interdependence of people, which means to what mutually connects them. It is a concept that can be related both to relatively small groups, and to big societies. Elias noted that he introduced the concept in order to express more clearly and unambiguously the fact that what we call society is neither an abstraction of the characteristics of existing individuals without society, nor the "system" or "the whole" excluding individuals, but rather a tangle of interdependencies created by individuals [Elias 2006a: 50].

Simpler and more transparent figurations are created by teacher and pupils in the classroom, doctor and patients in the therapeutic group, and regulars in the pub. More complex figurations are for example the residents of a village, city or nation. Chains of dependencies that bind such people together are not directly perceptible; they are very extensive and differentiated. The features of such complex figurations can be understood in more detail through the analysis of interdependency chains.

To illustrate the concept of figuration Elias likes to use the example of social dances [Elias 2006a: 50, 51; Elias 2006b: 28, 29], because he believes that the image of moving figurations of interdependent people dancing can help us to understand figurations such as family, city, state, or social formation. Let us imagine as a symbol of society a group of dancers performing court dances such as the française or quadrille, or a country round dance. The steps and bows, gestures and movements made by the individual dancer are all entirely meshed and synchronized with those of other dancers. If any of the dancing individuals were contemplated in isolation, the functions of his or her movements could not be understood. The way the individual behaves in this situation is determined by the relations of the dancers to each other.

The expressions and movements of individuals may in one way or another be individually coloured, but they are always focused on others. We can of course talk about dance and its rules in general, but we can hardly imagine it as something that exists completely outside human individuals. Like other social figuration, this figuration is relatively independent of specific individuals, but in general it cannot do without individuals.

Another analogy through which it is possible to demonstrate the issue of figurations, is that of a game [Elias 1970: 141-142]. If four people play cards, they form a figuration, their action is interdependent. Although it is possible in this case to talk about the game as something autonomous (and say for example: "the game is going slowly"), it is essential, however, that the course of the game comes from the mutual entanglement of action of the four individuals involved. Figuration in this case means the "changing pattern" that players as a whole mutually make with their actions, in which they are engaged not only with their intellect, but with their whole personality. This figuration is formed by a structure of interdependent tension, in which participating individuals can stand as allies and also opponents to one another. The structural features of figuration streams therefore include the "fluctuating balance of power" [ibid: 143], which is at least bipolar, but mostly multi-polar, and which constitutes an integral element of all human relationships.

People and figurations change; and though these changes are inseparable and interdependent they are on different levels and of different kinds. In contemporary, abundantly differentiated society, the actions of individuals interweave to form long chains of functional relationships. Each human individual is thus involved in many such chains; 
through the functions that he performs he is dependent on many other individuals, and they are dependent on him. Instead of the idea of the human being as something closed (homo clausus), Elias emphasizes the image of man as an "open personality", more or less autonomous in relation to other people, though never absolutely and totally autonomous, because each through their life is grounded, oriented and dependent on others. The chains of these dependencies - not as visible and tangible as iron chains - are strong enough, but also elastic and changeable, and their arrangement is expressed by the term social structures [Elias 2006b: 25]. In their framework there is a - greater or lesser space for individual decision making; there appear crossroads where people must make up their minds, and choices on which may depend the fate not only of themselves but of others.

Elias's sociology of figuration was widely discussed in the 1980's, when it was considered very promising, and hopes were placed in it. Today, with hindsight, we can say that these expectations were not fully met. One of the problems lies in the fact that Elias defined the concept of figuration very generally and roughly; he did not work it up in enough detail to be a fully understandable and unequivocally applicable research tool in the field of theory and research. Although today there is a considerable amount of special literature that uses the term figuration [e.g. Gabriel - Mennell 2011], those who use it often have to specify what they mean by it (and some researchers endow it with distinctive, subjectively framed ideas which can lead to problematic content-shifts, notably Gerard Noiriel [2012], who had little compunction in renaming Elias's figuration "configuration"). What is missing in particular in Elias's text is the resolution of the various structural levels at which the creation of figurations occurs, and specifics on the differences between these individual levels, because there is after all a difference between the figurations made by whist players, mazurka dancers, or the citizens of a modern state.

\section{Personality and history}

Even if within his sociology of figurations Elias constantly emphasizes the participation of individuals in the creation of social reality, he tends to capture these individuals in the position of typical (average) representatives of certain social groups, classes or masses of human beings, whose main characteristic is that they carry a certain, historically formed type of collective human psyche, and so habitus. What we rarely find in Elias is reflection on the role of real human individuals, even though that he rejects the idea that all people are of equal importance to the course of history. Elias argues that individual beings cannot be understood as passive vehicles of the social machine, and stresses that their individual character along with personal decisions may have a significant influence on the course of historical events, but he also adds that the decision-making process of individuals is always limited, variable and depends on the instruments of power under their control [Elias 2006b: 67].

Current sociological thinking typically only acknowledges individual influence on the microsocial level, where the approaches of social constructivism are often explored. However, a generally neglected question remains whether, and how, actors can influence the macrosocial level. This is highlighted by Nicos Mouzelis, who states that the problem cannot be successfully tackled if we do not take sufficiently into account that society is 
organized hierarchically, and ask what role is played within the hierarchy by so-called "macro-actors" [Mouzelis 2006: 20].

One of the problems to which contemporary sociological theory has no answer, and to which it even feels no need to look for an answer, is the question of how individuals can influence the macro-level of societal structures and processes. Even though the question of actors as creators of social reality is accorded an important place in contemporary sociology, it is usual that attention is focused only on small anonymous actors and their everyday activities, observed on the micro-social level. It appears that when sociology has to deal with phenomena on a macro-social level, it is not able in principle to think other than through functionalism.

Although the issue of individuals with society-wide influence is quite common and legitimate in historical science, sociology, by contrast - one might say "on principle" ignores it. With some simplification, we can say that, for many years, we have witnessed that while history tends to see social processes as the work of famous historical figures, sociology, on the contrary, tends to look at these processes as a manifestation of supra-individual social units, structures and powers, or social systems and their functions. Apart from contemporary orientations of historical research towards social history or the history of everyday life, we can say that for traditionally conceived history the past is mainly a concatenation of the acts of important individuals. Sociology, meanwhile, even contemporary sociology, sees in the past processes of social changes taking place at the level of culture, civilization and various forms of human coexistence or social formation. In other words, in historical science the individualistic approach is significantly gaining ground, whereas in historical sociology on the contrary the holistic approach is ever more dominant.

It is clear that a number of topics, particularly in the case of general trends in the development of culture, civilization or modernity, can be monitored adequately from a holistic perspective, but doing so may ignore the role played by important historical figures. There are, however, research matters where the influence of these figures cannot be completely ignored. One such is the issue of European development after the Second World War. To explain this historical stage just as the movement of anonymous masses, or the dynamics of general principles and tendencies, and ignore those who were the leaders and the "architects" of social transformations, would be inadequate. The individual element always plays a certain role in society, giving social development and social coexistence their specific features. As a result, new, unexpected phenomena emerge in social reality, and thus it is so difficult to predict social development. However, for understanding the problem of these individual "macro-actors", sociology lacks adequate theoretical and methodological instrumentation.

The conceptual apparatus which sociology has at its disposal, has its origins in the founders of sociological thinking. Max Weber developed the concept of three ideal types of domination (charisma, tradition and rational-legal) [Weber 1922], Vilfredo Pareto [1968] formulated the theory of elites, and Robert Michels [1931] focused his attention on party leaders. All of these older, but also more recent approaches, usually focus on the individual at the top of the social hierarchies identified as a particular social group or type, who also affected the social characteristics which from a sociological point of view may be considered essential, decisive and differentiating. However, what is mostly absent is an explanation of the mechanisms that enable these individuals' actions to be 
reflected in the formation of social structures. As an exception in this context we can mention Elias's analysis of the "royal mechanism", which the author gives in the second part of the work The Civilizing Process. Elias here shows that in court society, in which individuals are meshed into networks of interdependencies, the sovereign power is based on pitting potential opponents against each other. Thus they become worn out and none is strong enough to be able to turn against the ruler. In order to implement this policy, the absolute monarch uses his ability to split opportunities, goods and clerical functions. His action is determined by the effort to preserve the balance of power, according to the principle of "divide and rule", which Elias indicates likewise as the "royal mechanism" [Elias 2007].

The issue of how a particular individual can affect his society and era, was the topic of Elias' last work, a small book about Mozart [Elias 1991]. In it he focuses attention on the issue of brilliant talent in the history of art. While dealing with this, Elias tried to avoid two commonly encountered extremes. One of them is the approach dealing with the history of art as a succession of great personalities; the second, the reduction of the history of art to the mere transformation of structures and styles. Elias's approach to this issue can be explained by the metaphor of the coin and stamp. Everyone within society may be compared to a coin that is shaped by a stamp representing social pressures, under whose influence the individual is also to be found. But at the same moment everyone is a stamp that, by its action in society and on others, leaves its own mark [Elias 2006b: 68]. Basically, these are two interdependent functions which mutually determine their existences. Even Mozart's genius corresponds to this idea. Even he is represents both coin and stamp. Mozart's musical personality was formed by contemporary influences and musical practices that he mastered in a perfect way. But he also managed to improve these procedures, innovatively transforming and developing new forms of musical expression. The role of genius thus lies in being, more than contemporaries, not only a coin but also a stamp, leaving an imprint on structures of a given area (or areas) of human activity and affecting its further development.

Elias's little work on Mozart is often overlooked but in the context of the sociology of figuration is important because it shows how it is possible to approach the problem - so far generally paid very little attention in sociology - of the role played by specific figures in the framework of social development and the historical process. The approach that Elias offers is indicated rather generally but nevertheless provides important inspiration for further thought.

\section{The "Duplex" Conception}

In the next part of the article, we will try to outline a solution to the problem of the "society of individuals" that is significantly different from the Elias's conception. We start from the assumption that the problem we are dealing with can be successfully solved neither by progressively interchanging the individualistic and holistic perspectives, nor by an effort to maximize the mutual approach of action and structure. The solution that we propose has to some extent been inspired by Émile and his concept of "homo duplex" [Durkheim 1913, 1914 (1995)]. This strategy is not the transfer of dualism of action and structure to duality, as in the case of Giddens, but an approach in which all basic concepts - actor, action 
and structure - are grasped from a perspective that is indicated in the above-mentioned Durkheimian concept. In other words, that it is not just necessary for both perspectives to approach each other maximally, but, so to speak, to "blend" in a theoretical interpretation that demonstrates that the terms with which we work in sociological theory - actor, action and structure - are by their very nature dualistic, which means they are "duplex".

Durkheim notes that the human being is divided, and furthermore in an internally contradictory manner. He says that in each of us there are two consciousnesses, two aspects of our mental life: personal and impersonal. Our physical body, on the one hand, is the source of our endless needs and desires, of our egoism. Our socialized being, on the other hand, is the construct of the society that lives and acts through us and controls and diminishes the symptoms of our egoism through internalized moral principles.

Durkheim raises the question of the cause of the dualism of human nature and concludes that this antinomy "corresponds essentially with the dual existences that we simultaneously lead". One part of our existence is purely individual and rooted in our corporeality. The second part of our existence is social and in it we represent just an extension of society [ibid.: 30]. Society retains, according to the author, its own nature, and thus also demands quite different from those that are included in our individual nature. The interests of the whole are not necessarily identical with the interests of its parts. Therefore, society can neither form nor maintain its shape without requiring permanent sacrifices, which are difficult for us. Only by being superior to us does it force us to transcend ourselves. And to overcome ourselves means to strip off some element from our nature, which is not possible without greater or lesser degrees of tension [ibid.: 31].

In trying at this point to follow up Durkheim in a certain way and be inspired by his concept of "homo duplex", we want to emphasize and update even that which Durkheim himself pushed aside in his theory - the consistent projection of a dualistic view of man not only onto the concept of the actor, but also in all other key concepts of sociological theory. Durkheim frequently expresses himself in terms and ideas which have to a certain extent become obsolete and anachronistic. We would not wish now to attempt to defend all his partial claims, but we should make efforts to utilise the most powerful elements which in our opinion hold validity and topicality even up to the present day, which in particular means the inner ambiguity of "homo duplex". We would take and enhance this idea, but not strictly in the context and conceptual form in which the French sociologist uses it. We understand it rather as a kind of loose inspiration in exploring those issues which Durkheim did not deal with. ${ }^{1}$ We believe that in accepting this idea we can consistently derive further considerations on the nature of action, interaction, and structure, all of which may be looked at through prospect of "duplex".

In individualistic conceptions actions tend to be seen as one-way acts that come from the individual and in most cases are oriented outwards so as to impress something or someone in the outside world. However, from the dialectical perspective the whole thing is more complicated. In the very act, from the very beginning, alongside the actor there is the other side, the world in which certain elements are striving to operate. The fact that one begins to act confirms the relevance of the rest of the world (regardless of whether it relates

1 For this reason, in this text we do not engage in the specific context of religion and morality, in which the concept of "homo duplex" by Durkheim is set in or with the secondary literature that deal with this subject. 
approvingly or disapprovingly). Every act intended to achieve something in this world is actually at the same time confirmation of its importance.

A man driven by his individual will monitors the actions of his personal (Durkheim would probably say, egoistic) interests and intentions. However, this activity is simultaneously social, and for two reasons: first, it is oriented towards individuals and it must therefore reckon with the surrounding social reality, its rules and expectations; such action to one degree or another - reproduces some general role with its respective structural formulas, which, as structuration theory says, are both supportive but also limitations on actions. The acting individual could not be an actor if he did not go through the process of socializing and learning certain societal demands, but at the same time the individual in his action must make certain decisions and choices that are often dependent not only on the social situation, but also on his purely individual skills, interests and preferences. Both components in human action - individual and social - interrelate, condition and support each other.

In terms of work we could use two dimensions of action, distinguishing them by the terms "voluntarism" and "sociality". Voluntarism means that action express the individual will or interest of the acting persons who are its very strong driving force. Both components interact in the sense that one limits the other in the extent and degree to which they can be expressed in a specific action. ${ }^{2}$ In the existing theoretical conception voluntarism is often associated with the issue of motivation and choice; sociality is viewed as a problem for the anticipated action, which is mainly associated with the concept of its social role. While analytically it is possible to distinguish two components, it is extremely difficult because within action they may be multiply-linked.

Owing to the fact that the actions of human individuals relate to other individuals, there starts to exist a mutual influence; that is to say, interaction. These interactions may take different forms and intensities, ranging from ephemeral encounters to fixed steady relationships. Interaction theoretically described from the perspective "duplex" appears as a reciprocal relationship between two or more individuals, each of whom has individual and social components. Their individual actions also have a dual character; in each of them we may note a share of voluntarism and likewise sociality. In simplified model form it can be said that individuals A and B regard each other's alter ego, seeing that the other - like himself - has his own properties and dispositions and that in his activities he follows his personal interests and goals, but meanwhile also seeing that he acts as representative of a certain role or institution, conforming in one way or another to general structural rules, regulations and behavioural patterns. At the individual level it is the mutual confrontation of two personalities, at the social level it is a matter of the reproduction of role patterns and institutional rules. Both the individual and social components of personalities and actions can through interaction represent both facilitating and inhibiting factors, and appear interactively in many different combinations.

2 From the historical and cultural point of view it can be assumed that the proportions between voluntarism and sociality can be different in individual types of societies and social groups. As an example the choice of a life partner can help. In traditional societies the parents or relatives determine the life partner, and often they have to respect a variety of strict social rules; in modern society the individual usually has the right of choice, often based on very subjective criteria and feelings. 
From this perspective social structures can be understood as two levels of structural rules. On the first level there are the general rules that define the basic social institutions and set basic role positions and role activities. On the second level there are the specific rules that occur in the context of specific human groups, in which certain expectations are derived or enforced on the basis of the individual dispositions of their individual members; these are the rules that are somehow negotiated within these groups, or imposed by power or force.

To illustrate the proposed approach we may use the simple example of the nuclear family as representative of typical social institutions and primary social groups. When thinking about the family as an institution, we give attention to the general rules that define the content of basic roles (mother, father, child), or - if we accept the functionalist approach - that determine the content of the basic functions (reproductive, protective, emotional, economic, educational) carried out by this structural unit. However, if we focus on a particular family as a small social group, we should turn our attention to another level of rules which has been formed or imposed by the specific characteristics, requirements and possibilities of individual family members (e.g. the rules over who is to pick the toddler up from kindergarten, who mows the lawn, or who walks the dog). In this example, we note that institutional rules exist as if dictated by society, while the operating rules of specific human groups emerge from - to one extent or another - the individual characteristics of its members. In practice, the two types of rules interconnect in such a complementary way that it is hard to maintain any separation.

There are many similar examples we could mention that show the multilevel character of social structures. One instance would be a sporting event that takes place in accordance with the relevant rules of the sporting discipline, but the game itself is then further structured by the strategies and capabilities provided by the teams and their players. The functioning of various types of social groups, organizations and social systems can be considered in a similar way (eg. in the policy area, systems which generally can be described as democratic, applying democratic rules of governance, may differ in the specific form of their expression, both due to different procedural rules but also and in particular how the representatives of the leading political parties put into effect their power).

By no means do we want to deny that social systems are capable of self-regulation. The economic system most convincingly demonstrates this capability; it has a self-regulating mechanism that Adam Smith long ago dubbed "the invisible hand of the market". However, as the crisis in this system has recently clearly shown, what is really happening is not just the result of the activity of some unrestrained supra-individual forces and system mechanisms, but the result of many human actors, especially those who, as top managers of financial institutions, made fatally incorrect economic decisions, which, as it turned out, had a massive impact.

Concerning the question of individuals with society-wide influence, the explanation which is on offer outlines that those individuals who, because of their social status (elite or monopoly position), have the opportunity to influence social macrostructures, are able to complement the level of general macro-structural rules with a further specific layer of rules which reflect their distinctive characters, the specifics of their activities, visions, ideas, wishes, discoveries, or even limitations, pathological tendencies, perverted ideas or 
deviations. These may be dispersed, or even inflicted, on a societal scale, due to the power and influence these individuals hold. In such a way one can attempt to clarify - together with Plekhanov - "the roles of personality in history" both in positive and negative cases; in the above-mentioned way you can describe the substance of the impact of outstanding historical personalities as well as tyrants and dictators.

\section{Conclusion}

In this article we focus on problems of the traditional theoretical dilemma represented by the opposition of individualistic and holistic approaches. First, we have described the solution offered by Elias's conception of figurations, then we have tried to outline a solution, which is to some extent inspired by Durkheim's concept of "homo duplex". In this approach we wanted to show that not only the human individual, but all the social reality which is the subject of sociological research, should be seen in the unity of two aspects simultaneously. The theory whose outline we have tried to present should be constructed so as to reflect the idea that the all phenomena of social life can always be viewed from both perspectives. These two aspects are not only complementary, but internally mutually conditional, and any interpretation conducted only from the position of one of them is always necessarily one-sided and incomplete. Therefore we propose an approach to the formulation of theoretical concepts that reflects this ambiguity, showing that each surveyed problem can be approached from two perspectives at once. If we accept this presumption, then individual actor does not stand in opposition to supra-individual social structures and systems, but these concepts are so aligned that each of them always has its individual and its supra-individual (collective) component, and these are in mutual correspondence with other categories that are specified in a similar way. The approach we are talking about is still rather a set of theoretical hypotheses. We do not anticipate from such an approach working out all the problems related to the matter of duality of action and structure; on the other hand, however, we believe that it is a perspective worthy of further development.

\section{Bibliography}

Alexander, Jeffrey C. [1987]. Twenty Lectures: Sociological Theory Since World War II. New York: Columbia University Press.

Archer, Margaret S. [1995]. Realist Social Theory: The Morphogenetic Approach. Cambridge: Cambridge University Press.

Berger, Peter L. - Luckmann, Thomas [1999]. Sociální konstrukce reality: Pojednání o sociologii vědění. Brno: Centrum pro studium demokracie a kultury.

Bhaskar, Roy [1978]. On the Possibility of Social Scientific Knowledge and the Limits of Naturalism. Journal for the Theory of Social Behavior (8): 1-28.

Boltanski, Luc - Thévenot, Laurent [2007]. Über die Rechtfertigung: Eine Soziologie der Kritischen Urteilskraft. Hamburg: Hamburger Edition.

Bourdieu, Pierre [1998]. Teorie jednání. Praha: Karolinum.

Durkheim, Émile [1913]. Le probléme religieux et la dualité de la nature humaine. Bulletin de la Société Francaise de la Philosophie XIII: 63-113. 
Durkheim, Émile [1914]. La dualisme de la nature humaine et ses conditions sociales. Scientia XV: 206-222.

Durkheim, Émile [1926]. Pravidla sociologické metody. Praha: Orbis.

Durkheim, Émile [1995]. Dualismus lidské přirozenosti a její společenské podmínky. Antropologie, sociologie, historie. Cahiers du CEFRES, March, 8: 16-34.

Durkheim, Émile [2002]. Elementární formy náboženského života: Systém totemismu v Austrálii. Praha: OIKOYMENH.

Elias, Norbert [1970]. Was ist Soziologie? München: Juventa Verlag.

Elias, Norbert [1983]. Die höfische Gesellchaft: Untersuchungen zur Soziologie des Königtums und der höfischen Aristokratie. Frankfurt am Main: Suhrkamp.

Elias, Norbert - Scotson, John L. [1990]. Etablierte und Außenseiter. Frankfurt am Main: Suhrkamp Verlag.

Elias, Norbert [1991]. Mozart, Zur Soziologie eines Genies. Frankfurt am Main: Suhrkamp.

Elias, Norbert [2006a]. O procesu civilizace: Sociogenetické a psychogenetické studie. Díl I. Promèny chování světských horních vrstev na Západè. Praha: Argo.

Elias, Norbert [2006b]. Spoločnost' indivíduí. Bratislava: Kalligram.

Elias, Norbert [2007]. O procesu civilizace: Sociogenetické a psychogenetické studie. Díl II. Promèny společnosti. Nástin teorie civilizace. Praha: Argo.

Fay, Brian [2002]. Současná filosofie sociálních věd: Multikulturní přistup. Praha: SLON.

Gabriel, Norman - Mennell, Stephen (eds.) [2011]. Norbert Elias and Figurational Sociology: Processual Thinking in Sociology. Oxford: Wiley-Blackwell.

Giddens, Anthony [1984]. The Constitution of Society: Outline of the Theory of Structuration. Berkeley, Los Angeles: University of California Press.

Habermas, Jorg [1981]. Theorie des kommunikativen Handelns, Band 1, 2. Frankfurt am Main: Suhrkamp. Keller, Jan [2004]. Dějiny klasické sociologie. Praha: SLON.

Latour, Bruno [2005]. Reassembling the Social. An Introduction to Actor-Network-Theory. New York: Oxford University Press.

Layder, Derek [1994]. Understanding Social Theory. London: Sage.

Michles, Robert [1931]. Strany a vůdcové: $k$ sociologii politického stranictví. Praha: Orbis.

Mouzelis, Nicos [2006]. Sociological Theory: What Went Wrong? London, New York: Routledge.

Noiriel, Gérard [2012]. Úvod do sociohistorie. Praha: SLON.

Pareto, Vilfredo [1968]. The Rise and Fall of the Elites. Totowa (New Jersey): The Bedminster Press.

Parsons, Talcott [1966]. The Structure of Social Action: A Study in Social Theory with Special Reference to a Group of Recent European Writers. New York: The Free Press.

Simmel, Georg [1970]. Grundfragen der Sociologie (Individuum und Gesellschaft). Berlin: Walter de Gruyter.

Weber, Max [1922]. Wirtschaft und Gesellschaft: Grundriss der verstehenden Soziologie. Tübingen: J. C. B. Mohr (Paul Siebeck).

Weber, Max [1988]. Ueber einige Kategorie der verstehenden Soziologie. In. Weber Max: Gesammelte Aufsätze zur Wissenschaftslehre. Tübingen: J. C. B. Mohr (Paul Sibeck), pp. 427-474.

Weber, Max [1998]. Základní sociologické pojmy. In. Weber Max Metodologie, sociologie a politika. Praha: OIKOYMENH, pp. 135-171.

Jiři Šubrt (b. 1958) studied sociology and economics in the 1980's at Charles University in Prague. Since 1990 he has lectured at this university at the Faculty of Arts. In 2009, he founded and has since been leader of the Department of Historical Sociology at the Faculty of Humanities. He is the author and editor of several books published in the Czech language, which mainly deal with the theme of contemporary sociological theory, particularly with regard to issues of action, structure and social systems. Over the longer term he has also paid attention to the issues of time and memory, recently implementing a three year project focused on the empirical research of the historical consciousness of the Czech population. In the area of historical sociology he has focused on the problems of the civilization process, civilizational comparative analysis, social change and multiple modernities. 